\title{
Supergentrificação e capitalismo financeirizado: as novas fronteiras do espaço-capital na Colina de Santana, Lisboa
}

\author{
Super-gentrification and financialized capitalism: \\ the new frontiers of space-capital in Colina de Santana, Lisbon
}

Luís Mendes [l] Ana Jara [II]

\section{Resumo}

Este artigo foca-se nas recentes alterações no perfil do processo de gentrificação experimentado em Lisboa, reforçadas no âmbito da pós-crise capitalista 2008-2009 e na última fase de capitalismo financeirizado. Pretendemos identificar forças motrizes importantes da financeirização do ambiente construído e do setor imobiliário que estão na raiz da onda de supergentrificação que está a ocorrer em Lisboa na última década e que permitem maximizar uma produção capitalista do espaço urbano, agravando a segregação residencial, a polarização social e a injustiça espacial nesta mais recente fase do capitalismo financeirizado. 0 enfoque empírico centra-se na análise de evidências de uma protogentrificação que se parece afirmar na Colina de Santana, no centro histórico de Lisboa.

Palavras-chave: gentrificação; supergentrificação; financeirização; produção do espaço urbano; habitação; Lisboa; Colina de Santana.

\begin{abstract}
The paper focuses on recent changes in the profile of the gentrification process experienced in Lisbon, reinforced in the context of the 20082009 capitalist post-crisis and in the last phase of financialized capitalism. We intend to identify important driving forces in the financialization of the built environment and of the real estate sector that are at the root of the super-gentrification wave that has been occurring in Lisbon in the last decade. These forces allow to maximize a capitalist production of the urban space, aggravating residential segregation, social polarization and spatial injustice in this latest phase of financialized capitalism. The empirical analysis focuses on evidences of a proto-gentrification that seems to be consolidating itself at Colina de Santana, in the historic center of Lisbon.
\end{abstract}

Keywords: gentrification; super-gentrification; financialization; production of urban space; housing; Lisbon; Colina de Santana. 


\section{Introdução}

Num contexto de globalização económica e financeira e de acréscimo de competição interurbana à escala também mundial, o quadro das políticas de habitação e de regeneração urbana deve ser analisado à luz do projeto neoliberal, das suas evoluções recentes no âmbito da crise económico-financeira de 2008-2009 e dos efeitos que esta produziu na estrutura socioespacial nas cidades da Europa do Sul (Eckardt e Sánchez, 2015). Nos tempos recentes, o neoliberalismo continua a reinar, a despeito dos seus fracassos espetaculares, sendo o exemplo paradigmático o da crise económico-financeira recente de 2008-2009, na qual as políticas de austeridade se afiguram como única alternativa e solução (Blyth, 2013; Millet e Toussaint, 2013; Schui, 2014; Lurdes Rodrigues e Adão e Silva, 2015; Eckardt e Sánchez, 2015), marcando uma nova fase no que Harvey (2010, 2012, 2014, 2016) descreveu como "acumulação por espoliação", conceito que brilhantemente Sassen (2014) aplicou à economia-mundo. $\mathrm{Na}$ cidade-empresa, os governos municipais atuam como atores de negócios de redução de custos que gerem as suas cidades como empresas. Enfrentando cortes de impostos e outros cortes na sua receita, esses governos têm promovido crescentemente políticas de austeridade. Isso traduziu-se em menos serviços para os cidadãos e menos investimento em recursos, equipamentos e infraestruturas da cidade da maioria, especialmente no setor da habitação a preços acessíveis.

À inevitável precariedade da situação laboral dos trabalhadores mais desqualificados e dos grupos sociais mais desfavorecidos, acumulou-se a desregulação do mercado de habitação e do uso do solo urbano, que tende a valorizar um padrão mais aleatório na produção temporal e espacial dos acontecimentos urbanos e o fabrico de uma segregação residencial a escalas mais finas, agravando a fragmentação socioespacial. Esse padrão é produto social do jogo do mercado imobiliário pouco regulado, de processos especulativos de valorização fundiária e imobiliária, num contexto de crescente financeirização do ambiente construído. Os governos urbanos têm-se orientado por um modelo gestionário (gestão estratégica importada do meio empresarial) em que o uso dos recursos públicos se faz para atrair investimento; o fornecimento dos serviços passa a fazer-se pelo mercado e pelo setor privado; e são valorizadas as parcerias público-privadas.

Essas transformações no espaço urbano intensificaram-se em Portugal com a realidade económica, financeira e orçamental resultante da crise capitalista de 2008-2009, que impôs a adoção de novos modelos de gestão e de desenvolvimento do território, que passaram pela definição de políticas nacionais com vista a acautelar o sucesso dos compromissos subjacentes ao Programa de Assistência Financeira Internacional, obviamente condicionadores da atuação do Estado e dos demais setores públicos e privados, enquanto norma transnacional. O Memorando de Políticas Económicas e Financeiras, também conhecido como Memorando de Entendimento ou Plano da Troika, é um acordo de entendimento celebrado em Maio de 2011 entre o Estado Português e o Fundo Monetário Internacional, a Comissão Europeia e o Banco Central Europeu, visando ao equilíbrio das contas públicas e ao aumento da competitividade em Portugal, como condição necessária para o empréstimo de cerca de $80 \mathrm{mil}$ 
milhões de euros que essas três entidades concederam ao Estado português. 0 memorando propôs uma série de ações várias que tinha como meta estabilizar a dívida pública por volta do ano de 2013, acrescentando que tal refletia um apropriado equilíbrio entre as ações necessárias para restaurar a confiança dos mercados e assegurar que esse ajustamento não prejudicava excessivamente o desenvolvimento da economia e do emprego em nível nacional.

0 documento que deu entrada em vigor a 17 de maio de 2011 é profundamente marcado por um fundamentalismo de mercado e teve ramificações consequentes para o programa do governo português da altura, tendo produzido políticas nacionais de forte austeridade financeira (cortes na despesa social, contração do investimento público, aumento de impostos, etc.) e a reformas estruturais que resultaram num verdadeiro atentado aos direitos laborais e sociais (facilitação dos despedimentos, redução da duração e dos montantes de subsídios de desemprego, etc.). Uma dessas reformas foi a do novo regime de arrendamento urbano (NRAU) de 2012, alvo de forte contestação social, uma vez que é acusado de ter imposto um mecanismo de atualização de rendas que tem originado valores incomportáveis para muitos inquilinos sem que estejam estabelecidos os apoios sociais adequados e necessários, afetando as famílias de mais baixo estatuto socioeconómico, sobretudo no nível das cidades mais importantes, tais como Lisboa e Porto, onde se concentra o mercado de arrendamento.

Essas políticas nacionais refletiram-se nas políticas municipais. As narrativas de marketing urbano e racionalidade neoliberal, a viragem neoconservadora no governo da cidade tem como objetivo tornar Lisboa uma cidade mais competitiva, atraindo investimentos estrangeiros, visitantes, turistas, amarrando os fluxos de capital imobiliário ao seu ambiente construído, num quadro da globalização da concorrência entre cidades e lugares. Mas temos de recuar mais de uma década, para captar o início dessa virada neoliberal (neoliberal turn) nas políticas urbanas desde 2004 (criação das sociedades de reabilitação urbana), ${ }^{1}$ com a aprovação de uma série de pacotes de leis que foram surgindo sucessivamente defendendo uma visão pró-mercado no que respeita à habitação, favorecendo a iniciativa privada, as parcerias públicas-privadas e a competitividade no setor. ${ }^{2}$ Essa viragem neoliberal culminou com a aprovação em nível nacional da Nova Lei do Arrendamento Urbano em 2012, em conjunto com a simplificação da Lei do Alojamento Local em 2014, com os pacotes para atração de investimento estrangeiro - tais como o regime fiscal muito favorável para os Residentes Não Habituais (RNH) (já desde 2009) e para os Fundos de Investimento Imobiliário, bem como com o programa dos Golden Visa ou Autorização de Residência para Atividade de Investimento $-{ }^{3}$ e ainda com o regime excecional e temporário de reabilitação urbana ${ }^{4}$ no sentido da agilização e dinamização, flexibilizando e simplificando os procedimentos de criação de áreas de reabilitação urbana e de controlo prévio das operações urbanísticas de 2014. De acrescentar ainda, em nível local novamente, a liberalização do uso do solo urbano, após a reformulação do Plano Diretor Municipal de Lisboa (2012), tal como o rent gap existente na cidade centro, em virtude de um elevado número de edifícios devolutos e muito degradados, 0 que fornece, ao capital imobiliário, oportunidades únicas de rentabilizar os seus movimentos 
cíclicos e reproduzir-se com a geração de enormes mais-valias, coincidindo com uma Lisboa que entra no mercado global do imobiliário, atraindo novas procuras residenciais e se projeta internacionalmente. Ao mesmo tempo que o Estado central parece continuar a demitir da promoção de uma verdadeira política de habitação pública, integrada e inclusiva para todos, ganham terreno as parcerias público-privadas e a atração do capital privado, de forma a injetar dinamismo e competitividade no setor.

Acrescente-se, ainda, a criação recente do Fundo Nacional de Reabilitação do Edificado (FNRE), de 2016, ${ }^{5}$ fundo especial de investimento imobiliário orientado para o desenvolvimento e a concretização de projetos de reabilitação de imóveis e para a promoção do arrendamento, tendo em vista a regeneração urbana e o repovoamento dos centros urbanos. Não obstante ser, na sua génese, um instrumento de políticas públicas, pretende-se que seja estruturado e regulado pelas leis gerais vigentes, aplicáveis a fundos de investimento imobiliário, podendo nomeadamente recorrer, em situação de igualdade, aos programas e aos instrumentos financeiros disponibilizados pelo próprio Estado e pelas demais entidades públicas para fins de reabilitação urbana e de arrendamento habitacional. Pretende-se, igualmente, que o FNRE tenha como participantes iniciais um conjunto de entidades públicas da administração central e local e ainda do terceiro setor, sendo possível e desejável que outras entidades, públicas e privadas, incluindo pessoas singulares, proponham-se como potenciais participantes.

Nesse momento, todo esse quadro legal e fiscal é, desde o início deste século, responsável por esvaziar a habitação do seu estatuto de direito para ganhar o de mercadoria, à luz da financeirização do imobiliário. Pelo contrário, o poder público devia assumir um papel regulador e estabilizador do mercado imobiliário, que continua a seguir, ao sabor dos grupos mais privilegiados, menosprezando os direitos da população e dos comerciantes locais.

É à luz do quadro teórico de produção neoliberal do espaço urbano que pretendemos identificar essas importantes forças impulsionadoras da financeirização que estão na raiz da onda de uma gentrificação mais agressiva, que tem ocorrido em Lisboa na última década. 0 conceito de gentrificação para ser analisado estruturalmente deve ser enquadrado nas tendências de financeirização, mercantilização, privatização, acumulação por espoliação e de urbanismo austeritário, evidentes à luz do desmantelamento das políticas de assistência pública como uma tentativa de incentivar iniciativas económicas privadas, características dos governos urbanos neoliberais. Além disso, esse conceito mostra como o discurso de regeneração urbana, no âmbito da política de cidades e da produção estratégica de narrativas e discursos atrativos do urbano, visa, por um lado, manter a população existente na área, modernizar a economia urbana, aumentar as taxas de emprego e promover o crescimento económico. Mas, por outro lado, funciona também como um mecanismo de legitimação do poder e mobilização de grande investimento público que é usado para subsidiar os mais ricos, em vez de beneficiar os necessitados; é recanalizado para reproduzir os interesses da finança, fundos de investimento imobiliário, grandes grupos económicos, grupos de construção civil, empresários e promotores imobiliários, para além de elites capitalistas internacionais e outros, 
contribuindo para uma polarização social, acompanhada de agravamento da segregação residencial e aprofundamento da divisão social do espaço urbano.

\section{Gentrificação, financeirização e política de escalas na produção de habitação}

Por definição convencional, a gentrificação designa o movimento de chegada de grupos de estatuto socioeconómico mais elevado, geralmente jovens e de classe média, a áreas centrais desvalorizadas e abandonadas da cidade. 0 efeito é que essas áreas se tornam social, económica e ambientalmente valorizadas, sofrendo um processo de filtering up. É um processo de mudança socioespacial, no qual a reabilitação de imóveis residenciais situados em bairros da classe trabalhadora ou de génese popular/tradicional atrai a fixação de novos moradores relativamente endinheirados, levando ao desalojamento de ex-residentes que não podem continuar a pagar o aumento dos custos de habitação ou o arrendamento, que acompanham a regeneração. Por conseguinte, é um processo pelo qual os bairros pobres e de classe trabalhadora na cidade centro são requalificados, através da entrada de fluxos de capital privado e de proprietários e inquilinos da classe média e média-alta (Smith, 1996; Hall, 1998; Slater, 2013).

Na atualidade, a gentrificação ocorre de várias maneiras, em diferentes bairros, em diferentes cidades, envolvendo, portanto, uma variedade de protagonistas. Os processos subjacentes à gentrificação e às mudanças de reestruturação que se materializam no ambiente construído, que se vão produzindo, parecem ter sido esticados ao longo do tempo e do espaço. A gentrificação contemporânea tornou-se cada vez mais complexa, pois envolve diferentes atores e lugares, e as paisagens produzidas mudaram. Uma série de transformações derivadas de um novo contexto político e económico imposto pela globalização gerou uma nova forma de gentrificação significativamente diferente da que se observou durante décadas, do ponto de vista dos protagonistas e de novas procuras, como modalidades e estrutura de oferta. 0 que era causal, marginal e local passa a ser sistemático e é verdadeiramente global para todas as regiões do planeta, assumindo uma dimensão estratégica na cena do urbanismo neoliberal contemporâneo (Smith, 2005, 2009), no sentido de um urbanismo muito mais orientado para o mercado e, portanto, afetado por filosofias baseadas na promoção do consumo, na competitividade entre cidades e na privatização, no sentido de um maior protagonismo dos atores privados no processo de planeamento e produção da cidade. Mediada pela dialética entre os movimentos cíclicos de capital financeiro à escala transnacional e a produção de ambiente construído imobiliário à escala local intraurbana e alavancada por processos ditos de "regeneração urbana", ${ }^{6}$ a gentrificação não se resume hoje já apenas ao setor residencial e à habitação, abrangendo também a geografia funcional da cidade, englobando igualmente o comércio, o turismo e a governança. Por isso se tem vindo a falar também em gentrificação turística, comercial e até ideológica/moral (Lees, Bang Shin; López-Morales, 2015 e 2016). 
Na verdade, a partir da teoria crítica, percebemos que se trata de um processo de aburguesamento de bairros históricos, ou seja, uma acentuação da conotação residencial alto-burguesa. A gentrificação trata-se sempre de um fenómeno de substituição social classista e de reapropriação pela burguesia - e da própria e respetiva ideologia neoliberal e ordem simbólica subjacente - dos espaços de habitat populares das áreas antigas centrais. Tal processo implica quase sempre a expulsão dos antigos residentes, logo desalojamento e segregação residencial, culminando com um aprofundamento da divisão social do espaço urbano. Essas tendências são muito evidentes, sobretudo, numa extensão do conceito de gentrificação a recentes casos de grandes operações urbanísticas de renovação ${ }^{7}$ e reabilitação urbanas, $^{8}$ levadas a cabo por diversos agentes de produção do espaço urbano, já caracterizados por Lefebvre (2000): os proprietários fundiários, os promotores imobiliários, o Estado, as empresas e os cidadãos.

Num esforço de revisão da literatura sobre a evolução do conceito de gentrificação, Savage e Warde (1993) defendem que, para que esse processo ocorra no espaço urbano, tem de se dar uma coincidência de quatro processos: 1) uma reorganização da geografia social da cidade, com substituição, nas áreas urbanas centrais, de um grupo social por outro de estatuto mais elevado, ou seja, desalojamento direto ou indireto; 2) um reagrupamento espacial de indivíduos com estilos de vida e características culturais similares; 3) uma transformação do ambiente construído e da paisagem urbana, com a criação de novos serviços e uma requalificação residencial que prevê importantes melhorias arquitetónicas; 4) por último, uma mudança da ordem fundiária, que, na maioria dos casos, determina a elevação dos valores fundiários e um aumento da quota das habitações em regime de propriedade.

A gentrificação no espaço urbano intervém na produção e na organização do trabalho produtivo e da economia espacial, ao mesmo tempo que determina as relações de produção; é também, simultaneamente, produtora e produto, suporte das relações sociais e, portanto, tem um papel importante no processo de reprodução geral da sociedade urbana capitalista. Tem-se, com efeito, uma produção espacial que se manifesta sob as formas de apropriação, utilização e ocupação de uma dada área, num momento específico que se revela no uso, como produto da divisão social e técnica do trabalho e que, no seio do processo capitalista, produz uma morfologia espacial "fragmentada" e hierarquizada, contribuindo para um aprofundamento da divisão social do espaço urbano e da segregação residencial.

A gentrificação é uma questão ideológica, política, e é o processo de mudança urbana que melhor materializa a luta de classes no palco da cidade na contemporaneidade. As relações socioespaciais estruturadas pela gentrificação são reguladas pelas estruturas capitalistas, de forma a reforçar e reproduzir a riqueza e o poder da classe dominante, por via da acumulação por despossessão, expropriação, desalojamento e expulsão da classe dominada.

Nessa ideia de expansão da fronteira da gentrificação (dos seus protagonistas, produtos e atores), encontra-se contida uma combinação evocativa e dialética entre capital e território, entre o económico e o espacial. Os processos de desenvolvimento da cidade ou urbanização 
são a manifestação espacial do processo de acumulação de capital. De motor de crescimento desde os tempos da Revolução Industrial, a cidade tornou-se um espaço organizado para o (re)investimento de capital, em função de ciclos de valorização e desvalorização constantes. As contradições experimentadas no espaço construído são reproduzidas em parte devido aos passos dados para converter o capital financeiro no elo mediador entre o processo de urbanização (em todos os seus aspetos, inclusive a edificação de ambientes construídos) e as necessidades ditadas pela dinâmica subjacente do capitalismo (Harvey, 2010, 2014, 2016, 2018; Clarke, Larsen e Hanse, 2015; Carlos, 2007, 2015; Carlos, Santos e Alvarez, 2018; Rolnik, 2015; Peck e Whiteside, 2016; Aalbers, 2016; Ribeiro e Diniz, 2017; Santoro e Rolnik, 2017). Também, na gentrificação como processo de (re) desenvolvimento urbano, o capital imobiliário procura uma estratégia para se expandir, não só para dar resposta às necessidades de realização e descobrir novas frentes urbanas de mercado, mas também para satisfazer as exigências das fases seguintes do ciclo de acumulação.

Em termos empíricos, torna-se também necessária uma leitura da retrospetiva das políticas municipais de reabilitação urbana, cujo percurso, no caso da cidade de Lisboa, tem sido, à semelhança de Portugal, marcado por um caro desígnio de liberalização e de desbloqueio do mercado de habitação português. $\mathrm{Na}$ verdade, a cidade de Lisboa sempre foi muito resiliente à gentrificação, pelo menos até finais do século XX. Primeiro, os sucessivos pacotes legislativos de programas de reabilitação urbana dirigidos à melhoria das condições de habitabilidade dos residentes até início do século XXI funcionaram como travão às forças da gentrificação (Mendes, 2008, 2014). Segundo, o controlo das rendas estabelecido em 1948, com aplicação retroativa a 1942, em Lisboa e no Porto gerou uma política de congelamento das rendas nas décadas seguintes que fez com que as que vigoraram até a atualidade se mantivessem muito reduzidas, o que terá justificado uma fraca competitividade no mercado de arrendamento, não permitindo o despejo e a libertação dos fogos arrendados. Tal facto teve como consequência imediata uma grande imobilidade habitacional dos que já se encontravam instalados na cidade centro (onde 0 mercado de arrendamento é mais representativo) e uma deslocação para a periferia dos que procuravam habitação mais moderna, isto é, os jovens casais e os imigrantes. Contribuiu, ainda, para o acelerar da degradação do parque habitacional, uma vez que as rendas praticadas não compensavam aos senhorios os investimentos necessários à realização de obras de conservação-manutenção dos prédios.

Porém, como em Londres, Paris, Berlim, Barcelona, Veneza ou Amesterdão, só para mencionar apenas algumas cidades europeias, assim foi também em Lisboa. Na última década, a fronteira da gentrificação tem vindo a avançar e muito, por efeito de uma aceleradíssima turistificação. Não só se tem expandido em escala como tem mudado de contornos, de formas e de protagonistas. Sabemos que, até início do século $\mathrm{XXI}$, o processo era marginal e embrionário nas duas grandes cidades portuguesas de Lisboa e do Porto. Designou-se de pocket gentrification ou "gentrificação embrionária" (Mendes, 2006, 2008, 2014). Apelidava-se, assim, pois tratava-se de uma soft gentrification, o seu estádio era primário, tanto que o seu crescimento era lento e 
esporádico, manifestando-se no espaço urbano de forma pontual e fragmentada, numa pequena escala circunscrita e limitada a apenas alguns apartamentos ou, quando muito, a alguns quarteirões de bairro. 0 desalojamento era diminuto ou mesmo inexistente. Isto aconteceu, pois todas as políticas de reabilitação urbana, assumidas desde os anos 1970 até início do século XXI, eram muito protetoras dos inquilinos e das populações mais vulneráveis que viveram durante décadas no centro histórico, procurando fixá-los em contracorrente com o intenso processo de despovoamento sofrido, à medida que pela expansão suburbana se consolidava a área metropolitana.

Nesse momento, Lisboa vive um novo estádio de gentrificação em tudo diferente do anterior, muito devido a um redesenvolvimento urbano tendo como principais causas a explosão de diversas formas de alojamento turístico e a promoção de produtos imobiliários de luxo, promovidas,, sobretudo pelo e para o grande investimento estrangeiro injetado por proprietários de peso e grandes grupos económicos de promoção imobiliária e por uma elite capitalista transnacional endinheirada, especialmente no centro histórico, área mais nobre da cidade. A orientação do capital imobiliário, no âmbito do programa Golden Visa ou dos Residentes Não Habituais (programas estatais portugueses que visam à atração de investimento estrangeiro, nomeadamente pelo setor imobiliário) para a produção de produtos de habitação ou alojamento de luxo, demonstra claramente que este é um caso de supergentrificação - tal como cunhado por Lees (2003) e desenvolvido, por exemplo, por Atkinson et al. (2017) -, quando áreas específicas constituem foco de intenso investimento e consumo ostentatório por uma nova geração de "financiadores" super-ricos, uma verdadeira classe de elite capitalista transnacional, alimentada pelas fortunas das indústrias globais de finanças e de serviços corporativos. A elite da riqueza transnacional é um grupo de pessoas que têm sua origem em uma localidade, mas investem suas riquezas transnacionalmente, de acordo com fluxos de capital transfronteiriços e fazendo uso de reescalonamento nas geografias neoliberais do investimento financeiro. Essas pessoas focalizam a atenção na intercessão entre suas oportunidades de investimento e as redes legais e as condições produzidas pelas políticas fiscais de atração de investimentos estrangeiros, ao invés de empreendedores imobiliários, associações de habitação ou investidores institucionais, a que o grande capital imobiliário recorria tradicionalmente (Aalbers, 2012, $2015,2016,2017)$. Sobre esses agentes globais na constituição do complexo imobiliário financeiro pelo reescalonamento urbano, Santoro e Rolnik (2017) referem:

0 complexo imobiliário-financeiro tem articulado essa interdependência entre o setor imobiliário, as finanças e o Estado, espalhando-se por diversas frentes de expansão imobiliária pelo mundo. Em algumas dessas regiões, já pesquisadas por Aalbers, essa articulação conta com a ação dos chamados global players - ou agentes globais: fundos de investimento e empresas imobiliárias transnacionais que adentram mercados financeiros como forma de diversificar ativos e mitigar riscos, mas também para penetrar em localizações geográficas onde não têm presença, capilarizando-se territorialmente e submetendo a produção das cidades a sua lógica financeirizada. (p. 408) 
Descendo novamente à mudança de perfil da gentrificação em Lisboa. Atualmente, enquanto os marginal gentrifiers (os gentrifiers pioneiros) continuam a influenciar a área, a gentrificação torna-se frequentemente acompanhada por agentes imobiliários de maior envergadura e por esses global players na constituição do complexo imobiliário financeiro, e a reabilitação urbana começa a afigurar-se como estratégia política e económica prioritária para a revitalização do centro histórico e rentabilização dos seus edifícios abandonados e degradados, até vazios urbanos. Como resultado do aumento do volume de intervenções imobiliárias, as melhorias físicas e arquitetónicas tornam-se cada vez mais visíveis nessa fase. Consequentemente, os preços das casas nos bairros históricos começam a subir galopantemente, em virtude das distorções introduzidas no mercado de habitação permanente e de arrendamento a longo prazo, pelo aumento de oferta de alojamento turístico. Sem regulação ou controlo moderado sobre a subida das rendas, o processo de desalojamento expande-se para formas mais agressivas, à medida que os valores imobiliários dos bairros também aumentam e o Estado aprova legislação facilitadora da iniciativa privada e do despejo de habitantes e comerciantes locais. As melhores propriedades habitacionais e comerciais mantidas tornam-se parte do mercado da classe alta e média-alta de procura global, à medida que os proprietários procuram tirar proveito da notoriedade reforçada da área, o que acaba, por sua vez, a conduzir a um maior desalojamento. Atualmente, e a partir do início do século XXI, o processo de gentrificação em Lisboa expandiu as suas fronteiras. A escala e extensão, as modalidades de oferta, os agentes/protagonistas do processo, em tudo mudaram. A gentrificação tornou-se madura e afigura-se com contornos mais agressivos, o que implica desalojamento dos mais pobres e uma perspectiva da habitação esvaziada da noção de direito, para ganhar o estatuto de mero ativo financeiro para atração de investimento estrangeiro. Tendo-se, sobretudo, a cidade de Lisboa tornado num destino de procura internacional do imobiliário, a subida dos preços acompanha os rendimentos médios dessa procura que são muito elevados comparativamente aos nacionais e excluem 0 português médio da possibilidade de aquisição de habitação em Lisboa. Portanto, a questão já não é apenas a do desalojamento direto, que implica expulsão das pessoas das suas casas e bairros, negando-Ihes o direito à habitação e ao lugar, mas é também uma questão de desalojamento indireto, porque se está a impedir ou a negar o acesso dos grupos mais vulneráveis a esse lugar, ao mesmo tempo que se abre o caminho para permitir que os grupos mais favorecidos o possam fazer (Mendes, 2016, 2017, 2018a).

$\mathrm{Na}$ Europa do Sul, especialmente em Portugal, os efeitos da crise urbana fizeram sentir-se de forma mais intensa em virtude do colapso do mercado imobiliário já de si frágil, assente no estímulo à compra de casa própria nas últimas décadas, suportado pelo acesso fácil a crédito barato, em paralelo com o desenvolvimento de um modelo de expansão urbana assente na produção massificada de nova construção, sobretudo nas periferias das áreas metropolitanas, conduzindo a um gradual endividamento dos particulares em matéria de acesso a crédito para aquisição de habitação própria. Evidentemente, esses factos, em conjugação com o eclodir de uma fortíssima 
recessão económica desde 2008 e cujos resquícios ainda se sentem hoje, acompanhada pelo aumento do desemprego, dos impostos à classe trabalhadora e dos cortes nos apoios sociais aos grupos mais social e economicamente fragilizados, resultaram num crescimento pronunciado do incumprimento do pagamento das prestações por parte das famílias portuguesas às respetivas instituições bancárias credoras.

Nos últimos 6 anos, os preços da habitação para arrendamento aumentaram entre $13 \%$ e $36 \%$ e, para aquisição, subiram até $46 \%$, consoante as áreas da cidade, de que resulta, estima-se, uma taxa de esforço com a habitação situada entre $40 \%$ e $60 \%$ do rendimento familiar, quando os padrões comuns aconseIham uma taxa de esforço até $30 \%$. Na capital, desde 2013, por exemplo, a freguesia de Santa Maria Maior perdeu quase dois mil habitantes. Isto dá mais de um habitante por dia, nos 4 anos que vão de 2013 a 2017. 0 despovoamento não é um fenómeno recente no centro histórico de Lisboa, sendo que os registos estatísticos do INE indicam que essa sangria demográfica se iniciou nos anos 40 do século $\mathrm{XX}$, onde residiam 160 mil habitantes, residem agora 40 mil. Esse processo durante o século passado relacionou-se, sobretudo, com a expansão da suburbanização e com a consequente formação da Área Metropolitana de Lisboa. 0 último recenseamento populacional de 2011 não capta a perda populacional nos últimos anos agravada pelos despejos da nova lei das rendas de 2012 nem o impacto do alojamento local (turístico) no mercado de habitação local. 0 número de desalojamentos recentes no centro histórico de Lisboa é desconhecido, até pela falta de estudos diagnósticos que comprovem o que me parece ser uma evidência clara, mas invisível aos olhos da opinião pública e da sociedade civil. Todavia, várias associações de moradores e de defesa do direito à habitação falam no conhecimento de centenas de casos nos últimos anos, especialmente nas freguesias centrais de Santa Maria Maior, Misericórdia e São Vicente, o que, num universo de residentes de alguns milhares, é bastante significativo, tratando-se, ainda para mais, de populações vulneráveis e em risco social. Perante um cenário de rendas cada vez mais altas, aliado ao facto de os salários serem baixos para a maioria dos portugueses, o número de despejos disparou. De acordo com os últimos dados do Banco Nacional de Arrendamento (BNA), os despejos duplicaram desde 2013, e, em média, é despejada por dia cerca de 5,5 famílias, em todo o país. Segundo os dados do Ministério da Justiça, o número de pessoas despejadas em 2016 foi 91,7\% superior ao número contabilizado três anos antes, 0 que pode sugerir evidência das dinâmicas descritas (Mendes, 2018b).

Guerra, Mateus e Portas (2008) defendem que as transformações socioeconómicas da sociedade portuguesa contemporânea e do sistema político revestem-se de um enorme impacte no pensamento e na ação, levados a cabo pela intervenção pública no nível do alojamento. Em grande medida, o debate público e político em torno das dinâmicas habitacionais esvaziou a temática do "direito à habitação" para o centrar em questões de mercado, como o equilíbrio entre oferta e procura:

De facto, para a maioria dos países europeus, a necessidade quantitativa de alojamento é encarada como um problema pertencendo ao passado, e as políticas habitacionais são hoje encaradas como respostas a grupos sociais 
específicos mais do que estratégias globais de acessibilidade ao alojamento. As preocupações orientam-se particularmente para a regeneração urbana e, dependendo da gravidade, para tentativas de estabilização dos actualmente voláteis mercados habitacionais privados. No entanto, reconhece-se a especificidade da "questão habitacional" nos países da Europa do Sul traduzida na persistência de graves carências habitacionais, na informalidade da construção e na debilidade da intervenção pública. (p. 10)

Barata Salgueiro, André e Brito Henriques (2015), por exemplo, argumentam que, embora o efeito dos investimentos orientados para ações de regeneração urbana do último governo português, sobre as tão aguardadas dinâmicas da reabilitação do edificado e de revitalização funcional, continue ainda por estudar e avaliar de forma mais aprofundada; uma apreciação rápida permite concluir vários pontos. Primeiro, efetivamente, quando aplicadas no terreno, as ações de regeneração urbana aproximam-se muito dos moldes dos programas de urban renaissance britânicos, fazendo, sobretudo, uso de estratégias de embelezamento do espaço público, dando prioridade a territórios que pela sua excecionalidade podem, através do reinvestimento, oferecer amenidades únicas para a captação de investimento privado e redinamização da economia urbana. Segundo, os resultados parecem ter sido dececionantes no que concerne à reabilitação de áreas urbanas pobres e marginalizadas, o que significa menor atenção à matéria da justiça espacial urbana, especialmente grave num período de crise económica e de maiores dificuldades de acesso ao crédito pelos mais vulneráveis social e economicamente, agravando as condições de vida não só nos bairros mais pobres, mas também naqueles habitados por segmentos da classe média que foram severamente atingidos pela política de austeridade e pela escalada do desemprego dos últimos anos.

No caso das políticas públicas de reabilitação urbana e das políticas de habitação, podemos dizer que. ao invés da destruição sistemática da provisão pública de bens e serviços, o neoliberalismo influencia a governação urbana no sentido de uma recomposição sofisticada da figura do Estado no nível local, tornando-o um instrumento de mercadorização da vida urbana:

No campo específico das políticas habitacionais, o Estado passa cada vez mais de um agente provisor directo, para um Estado subsidiário e regulador. De facto, constatam-se tendências para a redução do papel directo do Estado na provisão de habitação social, reforçando-se os apoios ao acesso à habitação, ao mesmo tempo que se alteram os mecanismos pelos quais o Estado intervém nomeadamente através de políticas fiscais, políticas de parceria público-privadas e incentivos financeiros a diversos agentes. (Guerra, Mateus e Portas, 2008, p. 13)

Portanto, e embora a ideologia neoliberal pareça apontar para a redução do Estado a uma espécie de Estado Mínimo, não devemos confundir o neoliberalismo com o regresso ao puro laisser-faire e aos mercados livres que dispensam e até repudiam a intervenção do Estado na economia. 0 projeto neoliberal depende da capacidade coerciva, transformadora e mediadora do Estado para injetar competição nos processos sociais e económicos e, como tal, reestruturar os espaços da cidade contemporânea em torno do mercado como princípio único 
organizador da vida urbana coletiva e social. Portanto, o neoliberalismo não se concentra necessariamente na amputação das funções sociais das instituições públicas ou na destruição do Estado Social, mas converte essas funções em mecanismos que servem os seus interesses através de uma seletividade estratégica, um "intervencionismo de mercado" (Rodrigues e Teles, 2015). Não se trata tanto de reduzir o peso da despesa pública, mas sim de promover a entrada dos privados em múltiplas áreas da sua esfera tradicional - sendo a da reabilitação urbana um exemplo paradigmático - para, dessa forma, favorecer a sua mercadorização mais ou menos gradual. No nível da regeneração e da reabilitação urbanas, essa privatização envolve complexas engenharias mercantis com recurso a fundos de investimento imobiliário, parcerias público-privadas nem sempre transparentes, complexas subcontratações ou dispendiosos subsídios e incentivos fiscais, garantidos pelo domínio público, envolvendo um ativismo estatal permanente e constante. Construir um mercado nacional da regeneração e da reabilitação urbanas e, sobretudo, garantir o seu funcionamento e expansão progressivos, além de bastante dispendioso, exigem, dada a natureza do sector em causa, uma poderosa maquinaria estatal (Brenner, Peck e Theodore, 2013; Rossi, 2017; Harvey, 2010, 2014).

Daí que o apoio em parcerias seja uma característica nuclear de qualquer processo de regeneração urbana. Esta está principalmente preocupada com as dinâmicas organizacionais e institucionais de gestão da mudança urbana, logo, a mobilização do esforço coletivo é privilegiada por várias razões. Primeiro, porque providencia a base para que a tomada de decisões estratégicas seja participada e negociada.
0 que se prende também com a crescente exigência de participação por parte das populações, na definição de soluções mais indicadas para os desafios locais. Segundo, porque a regeneração urbana envolve quase sempre grandes investimentos que dificilmente podem ser suportados por uma só entidade, seja ela pública ou privada. 0 que acontece é que 0 processo da regeneração urbana é de tal forma ambicioso nos objetivos, no conjunto dos stakeholders, nos investimentos, que envolve e na extensão temporal que implica, que torna praticamente inviável ser levado a cabo individualmente. Um terceiro fator é o de que os problemas urbanos que carecem de resolução se revestem de grande complexidade e multidimensionalidade; logo as parcerias constituem-se pela participação como o modo mais eficaz de possibilidade de integração e abrangência das soluções propostas. Um quarto e último fator relaciona-se com o facto de as parcerias permitirem maior coordenação e complementaridade entre diferentes competências de diferentes agentes e, assim, ultrapassar as tradicionais barreiras institucionais (Roberts e Sykes, 2000; McCarthy, 2007; Tallon, 2010; Smith, 2012; O’Brien e Matthews, 2016).

Nesse contexto, o papel do Estado Neoliberal é exatamente criar, manter e conservar uma estrutura institucional apropriada às práticas do mercado, apesar de, depois de criadas, as condições não mais requererem intervenções que ultrapassem as de um Estado mínimo. Nesse sistema, ganha relevo a forma como a produção do espaço se realiza cada vez mais como condição geral da (re)produção capitalista, não só na produção de infraestrutura, como na de ambiente construído, formando o aparato necessário à reprodução ininterrupta 
do sistema. 0 objetivo do Estado Capitalista não é eliminar as contradições do sistema, mas atenuá-las, reproduzindo, no tecido social, a dinâmica da acumulação capitalista extraída da produção de ambiente construído. Cabe ao Estado, inserido na lógica do sistema capitalista, garantir a reprodução do capital, gerindo conflitos e contradições produzidos pelo próprio sistema e que podem interferir na plena realização do ciclo de capital, seja pela produção de infraestruturas, seja pelo controle dos salários de modo a mantê-los baixos, seja pelas políticas de concorrência e de regulação que formula (Lojkine, 1997; Lefebvre, 2000; Bourdieu, 2014; Jessop, 2016), agilizando de forma reescalonada as condições de reprodução dos interesses do capitalismo financeirizado e a ação dos global players do complexo imobiliário financeiro, mediante uma eficiente e lubrificada política de escalas (Brenner, Peck e Theodore, 2010; Brandão; Fernández; Ribeiro, 2018).

0 quadro português de políticas de habitação e de regeneração urbana que tem emergido no século XXI deve, portanto, ser compreendido não só nesse contexto de governança urbana neoliberal, promotora de estímulos ao mercado e à iniciativa privada, mas também nas transformações urbanas acarretadas por uma produção social do espaço típica da fase recente financeirizada do sistema capitalista. Todavia, torna-se também necessária uma retrospetiva das políticas municipais de reabilitação urbana, cujo percurso no caso da cidade de Lisboa tem sido, à semelhança de Portugal, marcado por um caro desígnio de liberalização e de desbloqueio do mercado de habitação português, tradicionalmente rígido.

Rodrigues, Santos e Teles (2016) argumentam, no seu estudo sobre a financeirização do capitalismo português, que o impacto desse processo no sector imobiliário não é exclusivamente derivado da liberalização e da desregulamentação dos mercados financeiros. Trata-se, de facto, de um processo de financiar toda a economia e a sociedade portuguesas, como produto social e histórico. Os autores sublinham o papel central que o Estado desempenha na sua condução ou posição e na integração internacional da economia portuguesa. $A$ condição semiperiférica de Portugal, combinando características dos países desenvolvidos e menos desenvolvidos, torna o país particularmente vulnerável a pressões externas (incluindo as decorrentes do processo de integração europeia) condicionando a sua trajetória de evolução à financeirização do capitalismo. De facto, as fraquezas históricas da economia e da sociedade portuguesas, bem como o contexto de um Estado-Providência insuficiente, favoreceram a opção de criar um mercado privado de habitação, dominado pelas finanças, sobre o qual o Estado nunca deixou de desempenhar um papel decisivo.

\section{Uma ambiciosa nova topografia para a Colina de Santana, em Lisboa}

A crise de 2008 e a entrada da troika impulsionaram fortemente essa viragem para uma cidade neoliberal, com a aprovação da Nova Lei do Arrendamento Urbano (2012) acompanhada de medidas para atração de investimento externo: Golden Visa (2012), o Regime fiscal para os Residentes Não Habituais (2009) e um muito favorecedor Regime Jurídico dos Fundos 
de Investimento Imobiliário (2010). Junta-se, a esse Estado de Exceção, o regime temporário de Reabilitação Urbana ${ }^{9}$ (2014) que simplifica os procedimentos de criação de áreas de reabilitação urbana (com benefícios fiscais) e de controlo prévio das operações urbanísticas (Mendes, 2014, 2016). Sob a capa de que o mercado se autorregula, o que o neoliberalismo esconde é que não prescinde da intervenção estatal; com as políticas públicas a abrir espaços de acordo com os interesses do mercado e sem regulamentação para conter a onda de especulação. Nesse enredo não será estranha a existência de uma imobiliária em forma de empresa pública - a Estamo - "que está vocacionada para tratar do imobiliário excedentário do Estado". ${ }^{10}$ Adquire a forma legal de um fundo de investimento imobiliário, detido pela Sociedade Gestora de Fundos Imobiliários Fundistamo que, por sua vez, é detida integralmente pela Parpública, responsável pelos processos de privatização de empresas públicas nacionais, como a EDP ou os CTT. É atrás desse encadeamento legal que vai permitindo a privatização de bens e serviços estatais, que a ideia de cidade e a de poder local estão a ser redefinidas. A "Lisboa da Estamo" é o terreno talhado para fixar os novos fluxos de capital imobiliário que conferem à cidade uma renovada forma de produção do espaço. 0 ano de 2006 foi marcado pelo anúncio público do fecho do Hospital do Desterro, coincidindo com a reativação da Estamo ${ }^{11}$ e da Fundistamo, ${ }^{12}$ que passaram a deter a propriedade desse hospital em 2007, num processo de compra ao Estado, desmantelamento e alienação que viriam a incluir a totalidade dos hospitais da Colina de Santana.
A Autarquia de Lisboa (Câmara Municipal de Lisboa, CML), há mais de 10 anos socialista, protagonizou uma mudança de paradigma, que colocou Lisboa a par da tendência global dos governos locais na gestão urbana, segundo um modelo neoliberal: tangível em produtividade, competitividade e subordinação às lógicas de mercado e ainda na produção de valores passíveis de serem transacionáveis - o que Harvey (1989) definiu como o empresariamento da gestão urbana. A CML redefiniu uma cidade atrativa para os grandes investimentos privados, com marketing urbano e legislação, como o PDM $2012^{13}$ para dar suporte a essa nova realidade. A reabilitação urbana, reclamada durante décadas, aconteceu, sobretudo, na forma de operações de reabilitação e de valorização imobiliária do seu edificado, por via dos agentes do setor privado. E tem dado forma a um processo de gentrificação de pressão crescente no centro, que vai expulsando residentes e aprofundando divisões sociais no espaço urbano.

A Colina de Santana bem podia ser o centro geográfico de Lisboa, mas a atenção a essa localização não é alheia aos hospitais que a caracterizam e que, durante séculos, serviram a população do país. Alvos dessa cobiça são os seus terrenos que, juntos, ${ }^{14}$ perfazem uma área maior do que a da Baixa Pombalina. A Colina de Santana, com cerca de 183 hectares, corresponde territorialmente a um "triângulo invertido", delimitado, grosso modo, a oeste pela avenida da Liberdade; à norte, pela avenida Fontes Pereira de Melo e, a este, pela avenida Almirante Reis, importantes avenidas de expansão e crescimento urbano (Figura 1). 
Figura 1 - Localização e delimitação territorial da Colina de Santana

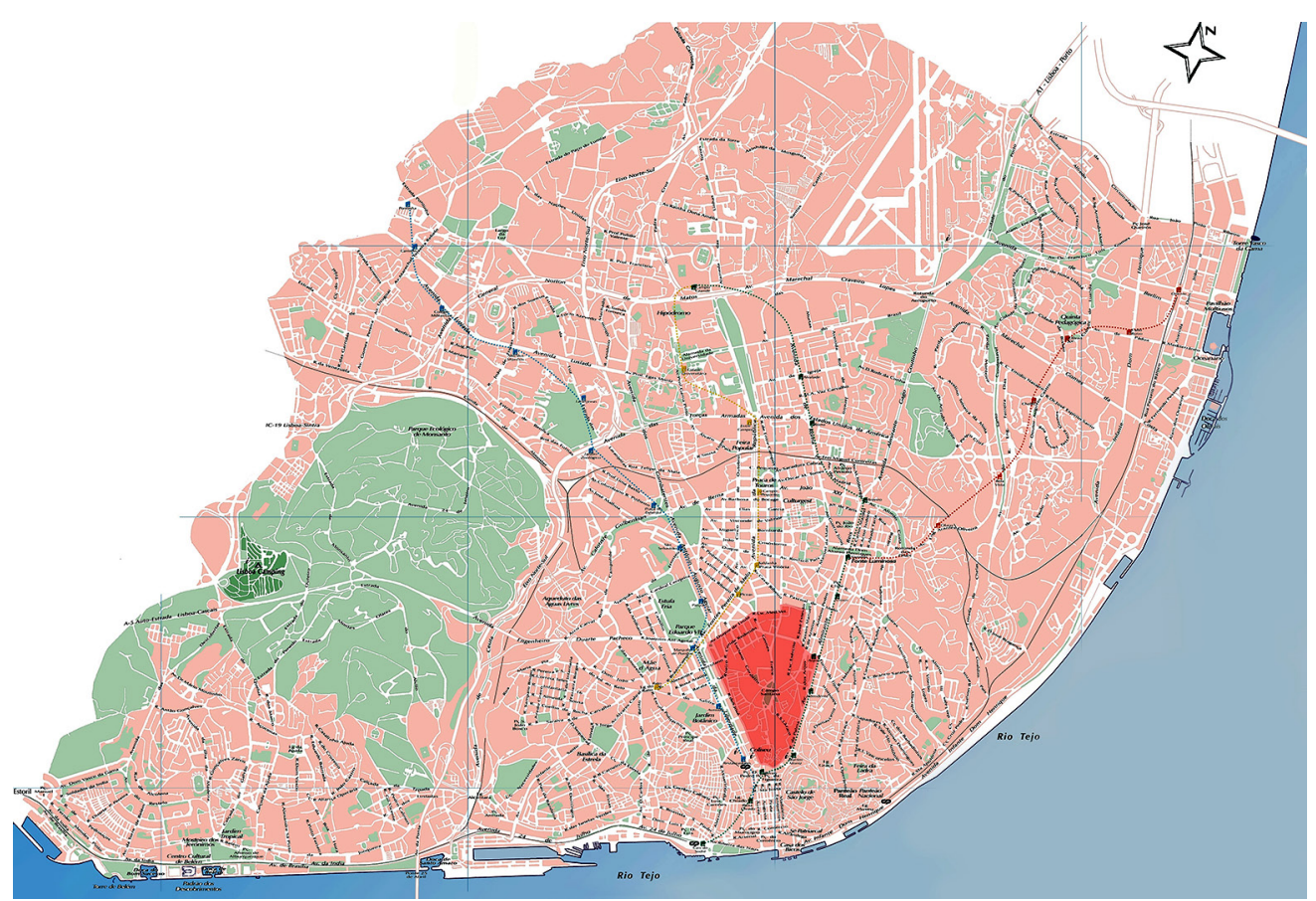

Sob a gestão do XVII Governo Constitucional (2005 a 2009), foi lançado o ponto de partida da operação - o plano para construção de um novo Hospital de Todos os Santos, com concurso público para a parceria público-privada (PPP) da sua construção e gestão, anunciado no ano de crise $2008^{15}$ - logo após a venda da CML de um terreno em Chelas (setor oriental da cidade) para a sua edificação (Figura 2).

Nessa articulação de forças, o Ministério da Saúde e a Administração Regional de Saúde de Lisboa e Vale do Tejo (ARS-LVT) criaram, em 2007, o Centro Hospitalar Lisboa
Central (CHLC), situado na Colina de Santana e que agrega, inicialmente, o São José, o Santa Marta, os Capuchos e a Estefânia. Em 2009, a Estamo compra 3 desses hospitais, ${ }^{16}$ passando - CHLC a pagar renda à Estamo. Acompanham esse processo rumores nos media que preveem o encerramento definitivo do CHLC e da sua substituição pelo novo hospital em Chelas. Apesar de fazer parte da lista de património de Estamo desde 2008, o Hospital Curry Cabral ${ }^{17}$ só em 2012 passa a fazer parte do CHLC juntamente com a Maternidade Alfredo da Costa - fazendo subir para 6 as unidades sujeitas à extinção anunciada desse centro hospitalar. 
Figura 2 - Cronologia da operação de revalorização da Colina de Santana

BREVE CRONOLOGIA DA OPERAÇÃO

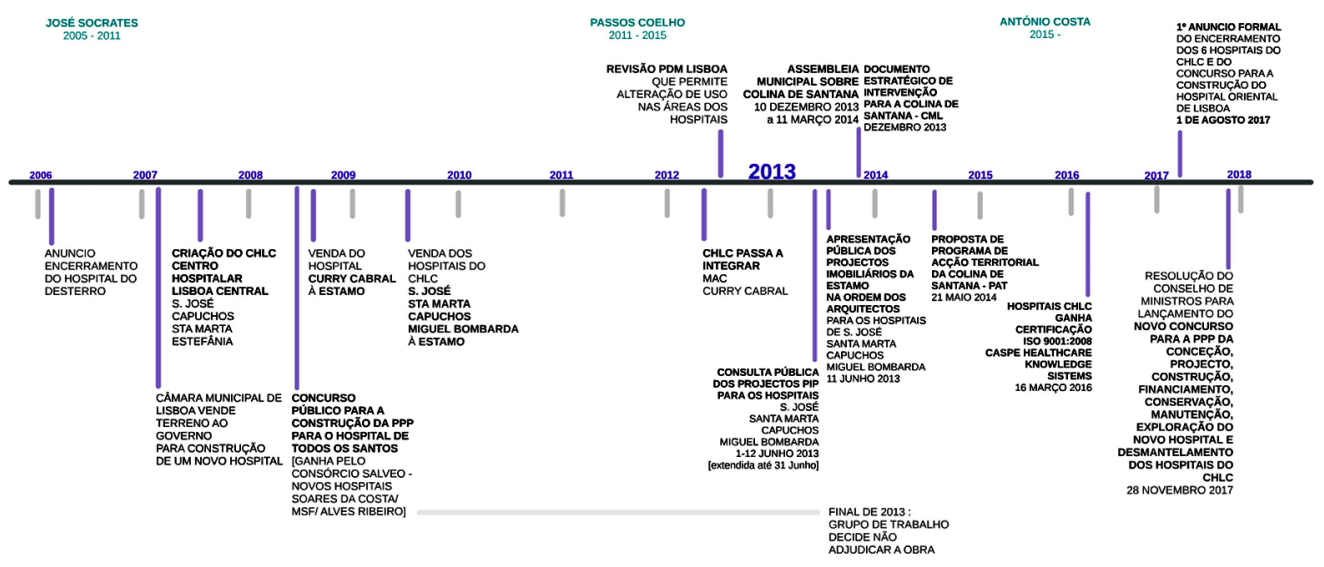

A revisão do PDM de 2012 foi executada com as necessárias alterações ao uso de solo, prevendo a operação urbanística de saída dos hospitais e a introdução de novos programas de uso privado, transformando os equipamentos públicos de saúde em projetos residenciais e hoteleiros de alta rentabilidade. Como consumação pública desse facto, a Estamo encomendou os projetos de arquitetura a reputados arquitetos, que foram o primeiro acesso mediático às intenções imobiliárias sobre a Colina. ${ }^{18}$ 0 tema chegou para promover um debate de 5 sessões na Assembleia Municipal de Lisboa, ${ }^{19}$ onde se convocaram todos os atores envolvidos. Para explicar essa operação, o presidente da Estamo, Francisco Cal, afirmou:

A Estamo é uma empresa de capitais públicos, mas é uma empresa especial, que é uma empresa que tem um capital social de 850 milhões de euros, portanto tem muito património, tem património que precisa de mudar os usos, para poder rentabilizar - isto é o caso desses imóveis - como também de imóveis arrendados ou desocupados. ${ }^{20}$

Essa afirmação revela a estratégica posição da Estamo que, por ser pública, se tem envolvido nos processos de produção capitalista da cidade, em favor da sua otimização privada, introduzindo claramente, no caso da Colina, a intenção de máxima rentabilização do terreno para a melhor venda a um hipotético proprietário.

A posterior integração dessa intervenção urbana em documento estratégico de intervenção da CML para a Colina de Santana ${ }^{21}$ não apaga a realidade de que não há, até hoje, estudos acessíveis que sustentem essa operação a montante dos projetos imobiliários da 
Estamo. A necessidade da construção de um novo hospital vem acompanhada de críticas a degradação, dispersão, disfuncionalidade e despesismo público do CHLC que, "só por viver em 6 edifícios envelhecidos, alguns deles centenários, tem um desperdício estrutural que se fixa por ano em 48 milhões". ${ }^{22}$ No essencial, esse discurso deve muito aos movimentos de reforma e modernização neoliberal que centram a sua atenção na incapacidade de o Estado gerir, por si só, setores económicos inteiros, pelo fraco dinamismo na resposta às reais necessidades do utente-consumidor-cidadão, pela ausência de efetivas economias de escala de controlo dos custos e dos dinheiros públicos e pela entropia diante da evolução tecnológica e social. De acordo com essa escola de pensamento neoliberal, o que está em causa é a obtenção de um serviço público de qualidade, prestado com eficiência, eficácia e economicidade, de preferência em articulação com o setor privado e com o mercado. Aumentar a qualidade e reduzir os custos é o princípio capital dessas novas posturas teóricas, que fomentam fortemente os processos de inovação na cultura do setor da administração pública. Esta é a narrativa que legitima a potencial destruição criativa na Colina de Santana.

A fusão dos 6 hospitais - feita em primeiro lugar pelo SNS e pela ARS-LVT - é próxima do momento da sua venda à Estamo, o que pode explicar elevados custos estruturais e parte da degradação a que foram votados. Essa ideia tem um importante contraponto na acreditação e certificação internacional de excelência que o CHLC recebeu em 2016. ${ }^{23} \mathrm{~A}$ idade das suas arquiteturas conventuais e hospitalares serve de pretexto para a sua obsolescência, mas perde validade quando esses edifícios surgem reconvertidos em hotéis e produtos imobiliários residenciais de luxo na carteira de projetos da Estamo. Além disso, a disponibilidade de terrenos que oferecem para novas construções é central e, por isso mesmo, ausente nos discursos, bem como os novos edifícios que foram sendo edificados para a sua ampliação e contínua atualização.

Os hospitais do CHLC pertencem ao grupo restrito dos hospitais mais diferenciados do país. ${ }^{24} 0$ novo hospital Oriental não substitui 0 CHLC e parece preparar a redução da oferta do Serviço Nacional de Saúde (SNS): a operação prevê que as 1.307 camas $^{25}$ existentes no CHLC passem a $875 .{ }^{26}$ A poupança que fará o SNS na sua manutenção é previsível na discrepância de escalas, em que o que se propõe construir equivale a menos camas e diminuição dos serviços prestados à população. 0 repetido discurso sobre a insustentabilidade do sistema público de saúde e sobre a necessidade urgente de novas unidades em parcerias público-privadas (PPP) levou o antigo presidente da ARS-LVT, Luís Cunha Ribeiro, ${ }^{27}$ um dos principais responsáveis por essa decisão, a afirmar que "seria quase um crime económico não construir o novo Hospital" ${ }^{28} 0$ custo da sua construção que foi inicialmente orçamentado em 600 milhões, ${ }^{29}$ pelo ministro Paulo Macedo, passou recentemente para 300 milhões, $^{30}$ para um hospital maior $^{31}$ e de construção em PPP - em que o Estado passará a pagar uma renda anual ao operador privado de 16 milhões de euros conforme anunciou o Secretário de Estado da Saúde da altura, deixando antever a prática de suborçamentação que se tem generalizado para obras públicas em todo o país. As rentabilizações possíveis da Colina e o concurso de PPP para um novo hospital no Vale de Chelas 
revelam-nos a centralidade dos assuntos de propriedade para a cidade e o papel do Estado na era neoliberal. Com tudo isto, as duas pesadas operações urbanísticas prosseguem misteriosamente irreversíveis à passagem de vários governos e ministérios.

Reativada durante o governo de José Sócrates, a Estamo foi um mecanismo estatal ao serviço de um alívio, a curto prazo, das contas públicas e da diminuição do valor do déficit público. Adquiriu não só "património excedentário", mas edifícios ocupados por serviços públicos que representam uma perpétua renda do Estado sobre imóveis que lhe pertenceram. Ao longo da última década, foi-se posicionando para comprar ao Estado muito do seu melhor parque imobiliário, que passou a estar assim acessível aos grandes grupos de investimento imobiliário, que são os seus clientes últimos. Pairam dúvidas sobre os critérios da venda de imóveis do Estado à Estamo e, em 2012, o Tribunal de Contas conclui "ser deficiente e inapropriada - ou mesmo inexistente - a fundamentação das decisões de alienação de imóveis" ${ }^{32}$ Sobram ainda dúvidas de que seja a Estamo a lucrar com a venda desse património. Em 2004, o Hospital de Arroios foi vendido às empresas Mavifa e Afer por 11 milhões e revendido, passadas poucas horas, por 21 milhões - o que revela indícios de especulação imobiliária -, apenas 4 dias depois de a CML ter aprovado, à Estamo, o projeto da sua demolição para nova construção. ${ }^{33}$

0 que torna particular a forma como opera a Estamo está escondido nas linhas do caso da Colina de Santana. A Estamo reserva sob a sua alçada os terrenos dos hospitais do CHLC e, ainda, os hospitais do Desterro e Miguel Bombarda. Desenvolve com eles projetos imobiliários que se apresentam como um todo, que operam urbanisticamente no território e que são apresentados com o suporte público da CML e passam inclusivamente a fazer parte dos seus Instrumentos Estratégicos. ${ }^{34}$ Com isto, a Estamo investe-se em fazer o (re)desenvolvimento urbano da Colina de Santana e, como Cavalo de Tróia, alavanca o início de um processo de gentrificação sem par num território consolidado. A influência da Estamo é, nesse ponto, decisiva para dar forma à produção do espaço urbano, escalando os interesses privados ao poder de tomar decisões urbanísticas com implicações estruturais no futuro da cidade. Pela sua complexa teia de influências entre Estado e setor financeiro, o que Harvey (2010) designa do nexo Estado-Finanças, o caso da Colina de Santana é revelador do papel de articulação de interesses da Estamo entre Estado, Ministério da Saúde, ARS-LVT, CML e os grupos de investimento privado da saúde e do imobiliário que se perfilam para concretizar esse processo duplo de privatização, antevendo um reforço do complexo imobiliário financeiro em Lisboa. Por evidenciar a sua opacidade e seu modus operandi, a Colina de Santana pode bem ser a ponta do iceberg da Estamo.

\section{Considerações finais}

Este artigo procurou demonstrar como a produção de espaço em geral e, em particular, a urbanização e a gentrificação tornaram-se um negócio ainda mais importante num contexto de crescente capitalismo financeirizado hegemónico, sendo uma das principais formas de absorver excedentes e garantir produção de mais-valias urbanas e reprodução do capital 
imobiliário financeiro. Uma proporção significativa da mão de obra global trabalha na construção e manutenção do ambiente construído e no setor imobiliário. 0 processo de (re)desenvolvimento urbano mobiliza grandes quantidades de capital, associado geralmente sob a forma de empréstimos de longo prazo. Esses investimentos baseados na dívida tornam-se frequentemente epicentros para a formação de crises capitalistas, como ocorreu com a crise de 2007-2008, mas também evidenciam o potencial da produção do urbano na absorção das irracionalidades e contradições do capitalismo financeirizado. 0 lado mais sombrio da absorção de excedentes pela reestruturação do espaço urbano implica, no entanto, repetidos surtos de transformação e restauração através da destruição criativa, enfatizando a importância desses momentos de reforma periódica do ambiente construído na coincidência com crises capitalistas. Esse processo tem uma dimensão de classe, pois geralmente são os pobres, os desfavorecidos e os marginalizados pelo poder político e económico quem mais sofre com isso (Harvey, 2010, 2014, 2016, 2018; Gottdiener, 1985).

0 capital financeiro para se reproduzir mais eficazmente no período contemporâneo fá-lo através do espaço urbano; ao mesmo tempo que produz o espaço enquanto sua exigência da acumulação continuada no espaço metropolitano e globalizado, coloca em questão o plano do habitar social decorrente das novas exigências da reprodução do capital investido, mas ativando novas modalidades no plano político, reforçando o nexo Estado-Finanças (Carlos, 2007, 2011; Carlos et al., 2015, 2017).

Como diz Harvey mais recentemente (2010, 2014, 2016, 2018), o capital esforça-se para produzir a paisagem geográfica favorável à sua própria reprodução e evolução posterior. A paisagem geográfica do capitalismo é, contudo, tornada perpetuamente instável por várias pressões técnicas, económicas, sociais e políticas que operam no mundo de variações imensamente variáveis. 0 capital deve, necessariamente, adaptar-se a esse mundo em constante evolução. Mas o capital também tem um papel fundamental na formação do mundo. A forma como a paisagem evolui e se organiza afeta a acumulação de capital, mas também as contradições do capital e do capitalismo se manifestam no espaço, no lugar e no tempo. A maneira independente na qual a paisagem geográfica evolui desempenha um papel fundamental na formação da crise capitalista. Sem um desenvolvimento geográfico desigual e suas contradições, o capital teria ossificado há muito tempo e caído em desordem. Este é um meio fundamental pelo qual o capital se reinventa periodicamente. 0 capital deve ser capaz de resistir ao choque da destruição do velho e estar pronto para construir uma nova paisagem geográfica sobre as suas cinzas. Os excedentes de capital e de trabalho devem estar disponíveis para esse fim. Felizmente, o capital, por sua própria natureza, perpetuamente cria tais excedentes, muitas vezes sob a forma de desemprego em massa do trabalho e uma sobreacumulação de capital. A absorção desses excedentes por meio da expansão geográfica e da reorganização espacial, nomeadamente pela reestruturação urbana, ajuda a resolver o problema dos excedentes que não dispõem de oportunidades lucrativas de reprodução. A urbanização e 0 desenvolvimento regional tornam-se esferas autónomas da actividade capitalista, exigindo 
grandes investimentos (normalmente financiados pela dívida) que levam muitos anos para amadurecer. As crises são essenciais à reprodução do capitalismo. É no curso da crise que as instabilidades do capitalismo são confrontadas, remodeladas e reestruturadas para criar uma nova versão do que o capitalismo é e pode ser. E isto através do espaço urbano que, por via da supergentrificação, enquanto estratégia de um urbanismo crescentemente neoliberal, afigura-se como meio e condição essencial para uma geografia (de reprodução) do capitalismo financeirizado transnacional.

No caso de Lisboa, a viragem neoliberal dos sucessivos pacotes legislativos para uma reabilitação urbana mais pró-mercado; os programas Golden Visa e Residentes Não Habituais; a nova lei de arrendamento urbano; o novo regime fiscal dos Fundos de Investimento Imobiliário; a nova lei do alojamento local (turístico); o fundo nacional de reabilitação do edificado - que recanalizaram o interesse de especulação imobiliária de uma elite capitalista transnacional -, juntamente com o forte crescimento da procura turística na cidade de Lisboa e a disponibilidade de um parque habitacional em avançado estado de degradação que cria oportunidades de gerar mais valias para a especulação imobiliária mediante rentabilização da rent gap, geraram uma "tempestade perfeita" que introduziu distorções significativas no mercado de habitação, no nível do segmento de habitação acessível para residência permanente ou para arrendamento de longa duração, que passou de uma pausa abrupta para um alto nível de demanda de forma muito rápida, com a oferta agora começando a ficar aquém de satisfação daquela. Essa situação levou a um rápido esgotamento do stock residencial novo e de boa qualidade que estava disponível, localizado principalmente no centro histórico da cidade, mas não apenas no segmento residencial de luxo. Despertou igualmente o interesse de muitos promotores imobiliários nacionais e internacionais, entre outros agentes/stakeholders globais do complexo imobiliário financeiro, levando a uma remodelação de edifícios nos bairros históricos de Lisboa, com vista ao desenvolvimento do alojamento turístico e de apartamentos de luxo. Com toda essa dinâmica, atualmente podemos assistir a um grande dinamismo na reabilitação de edifícios e na revitalização do espaço público no centro histórico da cidade, o que contribuí para o aumento contínuo da oferta desse tipo de alojamento, mas, ao mesmo tempo, desalojando a população mais pobre já residente no centro histórico, tais como imigrantes e idosos. A destruição do mercado de arrendamento e o desalojamento e despejo de antigos moradores são uma realidade para dar origem a diversos formatos de produtos imobiliários mercantilizados que ressignificam a habitação como mero ativo financeiro, esvaziando-a do conteúdo social enquanto direito constitucional básico do habitar e necessidade coletiva.

Existe uma grande expectativa em tornos dos eixos de promoção da reabilitação urbana e de desenvolvimento do mercado de arrendamento acessível anunciado pela Nova Geração de Políticas de Habitação, porque aposta na reabilitação como norma e não como exceção, para além de procurar adaptar 0 acesso à habitação em função do rendimento das famílias. Mas o facto de não se procurar regular o mercado de forma direta nem se ter manifestado intenção de revogar 
ou reestruturar a Lei das Rendas de 2012 e a restante legislação dos Golden Visa, Residentes Não Habituais, Fundos de Investimento Imobiliário, torna difícil antever a alteração da relação de forças que está a gerar essas desigualdades e injustiças socioespaciais em Lisboa. Todavia, a discussão que se tem tido na Assembleia da República sobre as possíveis alterações ao regime do Alojamento Local e os avanços de um Projeto de Lei de Bases da Habitação promete, com o compromisso de todas as forças políticas em torno da questão. É imperativo urgente que o Estado Central assuma efetivas funções de regulação no nível das políticas turismo e de habitação.

A decisão do Estado de desativar um conjunto considerável de equipamentos sobre a área confinada da Colina de Santana aconseIha a uma reflexão crítica sobre os impactes do consequente processo de reconversão urbana, de forma mais alargada, numa leitura integrada das mudanças recentes do território da cidade à luz da produção capitalista e financeirizada. A primeira revisão do PDM, em 2012, foi elaborada no pressuposto da desativação do conjunto dos Hospitais situados nessa área da cidade centro, assinalando essa possibilidade como oportunidade de regeneração urbana. Como principal preocupação, surge a possibilidade de desativação dos equipamentos sem uma intervenção física imediata, que provoque o efeito de esvaziamento com consequentes efeitos sociais e físicos nefastos, reforçando o rent gap e desencadeando um processo de supergentrificação potenciada pela reabilitação do edificado da área, com o aproveitamento do seu grande potencial turístico, associado à valorização de todo o património histórico existente, mas também pelas amenidades da área, tipicamente recatada e aprazível, onde se conseguem, ao mesmo tempo, um relativo isolamento e uma surpreendente proximidade ao Centro Histórico e eixos centrais da cidade. A possível desativação dos hospitais, ainda em funcionamento na área, e a sua afetação a outros usos, à semelhança dos espaços já desativados, assim como a transformação de outras grandes unidades, gerarão novas dinâmicas. Será essencial aproveitá-las, tanto no sentido de prevenir o abandono e a degradação, que serão gerados se aí não se intervier, quanto prevenindo reforço de tendências de especulação imobiliária e consequente segregação residencial e fragmentação socioespacial.

Sob o signo do Direito à Cidade, a regeneração da Colina de Santana afigura-se uma oportunidade única para promover abordagens baseadas no não mercado para habitação e desenvolvimento comunitário. A influência negativa da especulação ou de qualquer outra forma de geração de lucro fácil, baseada na propriedade e desprovida de investimento na comunidade local, deve ser ativamente desencorajada. Tal requer implementar políticas para penalizar todo e qualquer investimento especulativo, a fim de reduzir a quantidade de propriedade transacionável que possa catalisar aumentos abruptos e incontroláveis dos preços da habitação e desalojamento. Dar continuidade a uma política de reabilitação urbana pelas pessoas e para as pessoas, que valorize o direito à habitação, em detrimento de grandes e espetaculares intervenções de renovação e restauro para alienação de património público e sua venda ao desbarato, em benefício do capital e de investimento estrangeiros, alimentando ainda mais o poder do complexo imobiliário financeiro. 
Num momento em que, em Lisboa, o fenómeno de gentrificação é intenso e concentrado, a Colina e os seus hospitais estão expectantes do esgotar de oportunidades de negócio nas áreas centrais. Para mais tarde fica o desfecho planeado, no tempo certo para o investimento imobiliário fazer subir para Colina as gruas e as máquinas de obra e para pôr em marcha, nos terrenos hospitalares, a maior operação urbanística de transformação da cidade de Lisboa das últimas décadas. Assim vai a expansão das fronteiras da dialética espaço-capital em Lisboa, ao sabor de uma geografia pluriescalar do capitalismo financeirizado, que não se centraliza só nas cidades globais, mas constantemente reinventa e rearranja as geometrias de poder do complexo imobiliário financeiro de acordo com a diferenciação interna e 0 ajuste espacial na cidade que o capital transnacional exige, mediante reescalonamento das políticas urbanas.

\section{[I] https://orcid.org/0000-0001-5281-4207}

Universidade de Lisboa, Instituto de Geografia e Ordenamento do Território. Lisboa, Portugal. luis.mendes@campus.ul.pt

\section{[II] https://orcid.org/0000-0002-7458-3777}

Artéria Arquitectura e Reabilitação Urbana. Lisboa, Portugal. jara.ana@arteria.pt

\section{Notas}

(1) Decreto-lei n. 104, de 7 de maio de 2004, que criou o Regime Jurídico Excecional de Reabilitação Urbana de Zonas Históricas e de Áreas Críticas de Recuperação e Reconversão Urbanística.

(2) Para uma análise mais detalhada ver: https://www.academia.edu/12422078/Mendes_L._2014_ Gentrifica\%C3\%A7\%C3\%A3o_e_pol\%C3\%ADticas_de_reabilita\%C3\%A7\%C3\%A3o_urbana_ em_Portugal_uma_an\%C3\%A1lise_cr\%C3\%ADtica_\%C3\%AO_luz_da_tese_rent_gap_de_Neil_ Smith_Cadernos_Metr\%C3\%B3pole_vol._16_n.o_32_pp.487-511. Acesso em: 5 maio 2018.

(3) Que dá a possibilidade de investidores estrangeiros (nacionais de Estados terceiros) requererem uma autorização de residência para efeitos do exercício de uma atividade de investimento mediante o preenchimento de determinados requisitos, nomeadamente a realização de transferência de capitais, a criação de emprego ou a compra de imóveis.

(4) Decreto-lei n. 53/2014, de 8 de abril.

(5) Resolução do Conselho de Ministros n. 48/2016, de 10 de setembro. 
(6) A regeneração urbana consiste numa visão abrangente e integrada, que visa à resolução de problemas urbanos e que procura gerar mudanças duradouras no nível da condição económica, física, social e ambiental de áreas que tenham sido sujeitas a transformações/alterações.

(7) No caso português, a renovação urbana é uma ação que implica a demolição das estruturas morfológicas e tipológicas existentes numa área urbana degradada e a sua consequente substituição por um novo padrão urbano, como novas edificações. Por conseguinte, essas intervenções de renovação urbana desenvolvem-se sobre tecidos urbanos degradados, aos quais não se reconhece valor como património arquitetónico e histórico.

(8) Por reabilitação urbana devemos entender um processo de transformação urbana, compreendendo a execução de obras de conservação, recuperação e readaptação de edifícios e de espaços urbanos, com o objetivo de melhorar as suas condições de uso e habitabilidade, conservando, porém, o seu esquema estrutural básico e o aspeto exterior original.

(9) Decreto-lei n. 53/2014, de 8 de abril 2014; Regime Excecional para a Reabilitação Urbana (Reru) que visa à adoção de medidas excecionais e temporárias de simplificação administrativa, que reforçam o objetivo de dinamização, de forma efetiva, dos processos administrativos de reabilitação urbana.

(10) Francisco Cal, presidente da Estamo na sessão da AML, de 10/12/2013.

(11) “A Estamo é uma empresa pública criada em 1993, vocacionada para a compra ao Estado ou outros entes públicos e privados de imóveis para revenda, para arrendamento ou para alienar após ações de promoção e valorização imobiliária". Disponível em: www.estamo.pt. Acesso em: 10 maio 2018.

(12) "A Fundistamo é a empresa instrumental do grupo Parpública para atividade de gestão de Fundos de Investimento Imobiliário". Disponível em: www.fundistamo.com. Acesso em: 10 maio 2018.

(13) O Plano Diretor Municipal passa de modelo normativo para estratégico; o conceito de Área Histórica extingue-se por se alargar a toda a Lisboa, e, com ela, a ideia de Área de Reabilitação Urbana (ARU) estende-se à quase totalidade da cidade. Essa condição e a falta de regulamentação sobre os usos permitem que um investidor possa aceder a benefícios fiscais do Estado e a "créditos de edificabilidade transacionáveis" (outra inovação desse PDM) a pretexto de "reabilitar" um imóvel.

(14) Hospital de São José, Hospital dos Capuchos, Hospital de Santa Marta, Hospital Dona Estefânia, do CHLC; Hospital de São Lázaro, Hospital Miguel Bombarda, Hospital do Desterro - encerrados; e, fora da Colina de Santana, Maternidade Alfredo da Costa e Hospital Curry Cabral, do CHLC.

(15) Concurso Público Internacional "Procedimento de Contratação com Qualificação Prévia para a Celebração do Contrato de Gestão do Edifício Hospitalar do Hospital de Todos os Santos" em abril de 2008. A CML já tinha vendido os terrenos ao Ministério da Saúde em 2007.

(16) A Estamo adquire o Hospital de S. José por 39.980.750 euros, o Hospital de Santo António dos Capuchos por 28.699.500 euros e o Hospital de Santa Marta por 17.860 .000 euros.

(17) Hospital Curry Cabral, vendido à Estamo, em 2008, por 20 milhões.

(18) Os projetos de arquitetura são apresentados em sessão pública na Ordem dos Arquitectos, em 11/7/2013. Disponível em: http://www.cm-lisboa.pt/noticias/detalhe/article/estudo-urbanoda-colina-de-santana. Acesso em: 5 maio 2018. 
(19) O Debate Temático sobre a Colina de Santana, na AML, tem 5 sessões que decorreram entre 10 de dezembro de 2013 e 11 de março de 2014.

(20) Francisco Cal, na Assembleia Municipal de Lisboa, em 10/12/2013.

(21) "Plano de Acção Territorial para a Colina de Santana" da CML, de 21/5/2014. Disponível em: http://www.cm-lisboa.pt/fileadmin/VIVER/Urbanismo/urbanismo/Licenciamento/ Proposta_n_._221-2014.pdf. Acesso em: 10 maio 2018.

(22) Ministro da Saúde, Adalberto Campos Fernandes, no programa Grande entrevista, da RTP 1, em $12 / 10 / 2016$.

(23) O CHLC recebeu em 16/3/2016 a Acreditação e a Certificação ISO 9001:2008, pela prestigiada entidade acreditadora do Reino Unido - Caspe Healthcare Knowledge Systems. A acreditação foi para a totalidade das 40 áreas clínicas e não clínicas.

(24) Hospitais de Referência, desde 2016 designados por Tipologia A1; com serviços únicos em nível nacional, como é o caso do Serviço de Transplante Pulmonar de Santa Marta e o Serviço de Transplante Hepático do Curry Cabral.

(25) Dados de dezembro de 2016, Administração Central do Sistema de Saúde - ACSS; de notar que para os 6 hospitais do CHLC, de 2003 a 2016, há uma redução de 40\% no número de camas.

(26) De acordo com ARS-LVT (ofício 7797/CD - SEC/2017), em resposta à AML sobre "Rede de Equipamentos Hospitalares na Cidade de Lisboa".

(27) Presidente da ARS-LVT, de 2011 a 2015, demitiu-se na sequência do caso da morte de um jovem no Hospital de S. José. Em 13/12/2016 foi detido e constituído arguido por suspeitas de corrupção no âmbito da Operação Máfia do Sangue.

(28) Na sessão da AML de 10/12/2013.

(29) http://observador.pt/2015/02/20/futuro-hospital-de-lisboa-vai-ser-maior-que-inicialmenteprevisto/. Acesso em: 12 maio 2018.

(30) https://www.portugal.gov.pt/pt/gc21/comunicacao/noticia?i=20170801-ses-hospital-o. Acesso em: 12 maio 2018.

(31) O Hospital Lisboa Oriental passou de 785 camas, com o Ministro da Saúde Paulo Macedo (20112015) ,para 875 camas com o atual Ministro Adalberto Campos Fernandes.

(32) In "Auditoria à alienação de Imóveis do Estado a Empresas Públicas", Tribunal de Contas, Dezembro 2012. Disponível em: https://www.tcontas.pt/pt/actos/rel_auditoria/2012/2s/auditdgtc-rel041-2012-2s.pdf. Acesso em: 10 maio 2018.

(33) https://sol.sapo.pt/artigo/32419/hospital-vendido-por-11-milhoes-e-comprado-por-21-milhoesminutos-depois. Acesso em: 10 maio 2018.

(34) De acordo com o Plano Diretor Municipal de 2012 e o Plano de Ação Territorial para a Colina de Santana de 2014. 


\section{Referências}

AALBERS, M. (2008). The Financialization of Home and the Mortgage Market Crisis. Competition \& Change, v. 12 , n. 2, pp. 148-166.

(eds.) (2012). Subprime cities: the political economy of mortgage markets. Oxford, Wiley Blackwell.

(2015). "Cities and the financial crisis". In: WRIGHT, J. (eds.). The encyclopedia of social and behavioral sciences. Oxford, Elsevier, pp. 579-584.

(2016). The financialization of housing: a political economy approach. Londres, Routledge.

(2017). The variegated financialization of housing. International Journal of Urban and Regional Research, v. 41, n. 4, pp. 542-554.

ATKINSON, R.; BURROWS, R.; GLUCKSBERG, L.; KEI HO, H.; KNOWLES, C. e RHODES, D. (2017). “Minimum city? The deeper impacts of the 'super-rich' on urban life". In: FORREST, R.; WISSINK, B. e KOH, S. Y. (eds.). Cities and the superrich: real estate, elite practices and urban political economies. Londres, Palgrave, pp. 253-272.

BARATA SALGUEIRO, T.; ANDRÉ, I. e BRITO HENRIQUES, E. (2015). “A política de cidades em Portugal: instrumentos, realizações e perspectiva”. In: NETO, P. e SERRANO, M. M. (coords.). Políticas públicas, economia e sociedade: contributos para a definição de políticas no período 2014-2020. Alcochete, Nexo Literário, pp. 49-82.

BLYTH, M. (2013). Austeridade. A história de uma ideia perigosa. Lisboa, Quetzal.

BOURDIEU, P. (2014). Sobre o Estado. Lisboa, Edições 70.

BRANDÃO, C. A.; FERNÁNDEZ, V. R. e RIBEIRO, L. C. de Q. (orgs.) (2018). Escalas espaciais, reescalonamentos e estatalidades: lições e desafios para a América Latina. Rio de Janeiro, Observatório das Metrópoles/Ippur/UFRJ/Letra Capital.

BRENNER, N.; PECK, J. e THEODORE, N. (2010). Variegated neoliberalization: geographies, modalities, pathways. Global Networks, v. 10, n. 2, pp. 182-222.

(2013). "Neoliberal urbanism: cities and the rule of markets". In: BRIDGE, G. e WATSON, S. (eds.). The New Blackwell Companion to the City. Oxford, Wiley Blackwell, pp.15-25.

CARLOS, A. F. A. (2007). O espaço urbano: novos escritos sobre a cidade. São Paulo, Labur Edições. (2011). A condição espacial. São Paulo, Contexto. (org.) (2015). Crise urbana. São Paulo, Contexto.

CARLOS, A. F. A.; VOLOCHKO, D. e ALVAREZ, I. P. (orgs.) (2015). A cidade como negócio. São Paulo, Contexto.

CARLOS, A. F. A.; ALVES, G. e PADUA, R. F. de (orgs.) (2017). Justiça espacial e o direito à cidade. São Paulo, Contexto.

CARLOS, A. F. A.; SANTOS, C. S. e ALVAREZ, I. P. (orgs.) (2018). Geografia urbana crítica: teoria e método. São Paulo, Contexto. 
CLARK, E.; LARSEN, H. e HANSEN, A. (2015). Financialisation of built environments: a literature review. Leeds, Fessud.

ECKARDT, F. e SÁNCHEZ, J. R. (2015). City of crisis. The multiple contestation of southern european cities. Bielefeld, Transcript Verlag.

GOTTDIENER, M. (1985). The social production of urban space. Austin, University of Texas.

GUERRA, E.; MATEUS, A. e PORTAS, N. (eds.) (2008). Contributos para o Plano Estratégico da Habitação 2008-2013. Relatório 3 - Estratégia e modelo de intervenção. Lisboa, IHRU.

HALL, T. (1998). Urban geography. Londres, Routledge.

HARVEY, D. (1989). From manageralism to entrepreneurialism: the transformation in urban governance in late capitalism. Geografiska Annaler, v. 71B, n. 1, pp. 3-17.

(2010). The enigma of capital and the crisis of capitalism. Oxford, Oxford University Press.

(2012). Rebel cities: from the right to the city to the urban revolution. Londres, Verso.

(2014). Seventeen contradictions and the end of capitalism. Oxford, Oxford University Press.

(2016). The ways of the world. Oxford, Oxford University Press.

(2018). Marx, capital and the madness of economic reason. Oxford, Oxford University Press.

JESSOP, B. (2016). The state: past, present, future. Cambridge, Polity Press.

LEES, L. (2003). Super-gentrification: the case of Brooklyn Heights, New York City. Urban Studies, v. 40, n. 12 , pp. 2487-2509.

LEES, L.; BANG SHIN, H. e LÓPEZ-MORALES, E. (eds.) (2015). Global gentrifications: uneven development and displacement. Bristol, Policy Press.

(eds.) (2016). Planetary gentrification. Bristol, Policy Press.

LEFEBVRE, H. (2000). La production de l'espace. Paris, Anthropos.

LOJKINE, J. (1997). O Estado capitalista e a questão urbana. São Paulo, Martins Fontes.

LURDES RODRIGUES, M. e ADÃO E SILVA, P. (orgs.) (2015). Governar com a Troika: políticas públicas em tempo de austeridade. Coimbra, Almedina.

McCARTHY, J. (2007). Partnership, collaborative planning and urban regeneration. Aldershot, Ashgate.

MENDES, L. (2006). A nobilitação urbana no Bairro Alto: análise de um processo de recomposição socio-espacial. Finisterra, v. 41, n. 81, pp. 57-82.

(2008). A nobilitação urbana no Bairro Alto: análise de um processo de recomposição sócio-espacial. Tese de Mestrado. Lisboa, Universidade de Lisboa.

(2014). Gentrificação e políticas de reabilitação urbana em Portugal: uma análise crítica à luz da tese rent gap de Neil Smith. Cadernos Metrópole. São Paulo, v. 16, n. 32, pp. 487-511.

(2016). "What can be done to resist or mitigate tourism gentrification in Lisbon? Some Policy Findings \& Recommendations". In: GLAUDEMANS, M. e MARKO, I. (eds.). City making \& tourism gentrification. Tilburg, Stadslab, pp. 34-41.

(2017). Gentrificação, financeirização e produção capitalista do espaço urbano. Cadernos Poder Local, n. 8, pp. 56-86. 
MENDES, L. (2018a). "Tourism gentrification in Lisbon: The panacea of touristification as a scenario of a post-capitalist crisis". In: DAVID, I. (eds.). Crisis, austerity and transformation: how disciplinary neoliberalism is changing Portugal. London, Lexington, pp. 25-48.

(2018b). Gentrificação turística em Lisboa: impactos do alojamento local na resiliência e sustentabilidade social do centro histórico. Poder Local, Revista de Administração Democrática, n. 155 , pp. 58-73.

MILLET, D. e TOUSSAINT, E. (2013). A crise da dívida. Auditar, anular, alternativa política. Lisboa, Temas e Debates, Círculo de Leitores.

O'BRIEN, D. e MATTHEWS, P. (2016). After urban regeneration: communities, policy and place. Bristol, Policy Press.

PECK, J. e WHITESIDE, H. (2016). "Financializing the entrepreneurial city”. In: SCHÖNING, B. e SCHIPPER, S. (eds.). Urban austerity: impacts of the global financial crisis on cities in Europe. Berlim, Theater der Zeit, pp. 21-39.

RIBEIRO, L. C. de Q. e DINIZ, N. (2017). Financeirização, mercantilização e reestruturação espaçotemporal: reflexões a partir do enfoque dos ciclos sistêmicos de acumulação e da teoria do duplo movimento. Cadernos Metrópole. SãoPaulo, v. 19, n. 39, pp. 351-377.

ROBERTS, P. e SYKES, H. (2000). Urban regeneration: a handbook. Londres, Sage.

RODRIGUES, J. e TELES, N. (2015). “O neoliberalismo como intervencionismo de mercado". In: BERNARDO, L. (org.). Correntes invisíveis: neoliberalismo no século XXI. Lisboa, Deriva, pp. 71-82.

RODRIGUES, J.; SANTOS, A; TELES, N. (2016). A financeirização do capitalismo em Portugal. Lisboa, Actual.

ROLNIK, R. (2015). Guerra dos lugares. A colonização da Terra e da moradia na era das finanças. São Paulo, Boitempo Editorial.

ROSSI, U. (2017). Cities in global capitalism. Oxford, Polity Press.

SANTORO, P. e ROLNIK, R. (2017). Novas frentes de expansão do complexo imobiliário-financeiro em São Paulo. Cadernos Metrópole. São Paulo, v. 19, n. 39, pp. 407-431.

SASSEN, S. (2014). Expulsions: brutality and complexity in the global economy. Nova York, Harvard University Press.

SAVAGE, M. e WARDE, A. (1993). Urban sociology, capitalism and modernity. Londres, Macmillan.

SCHUI, F. (2014). Austeridade. Breve história de um grande erro. Lisboa, Editorial Presença.

SLATER, T. (2013). “Gentrification of the City". In: BRIDGE, G. e WATSON, S. (eds.). The new blackwell companion to the city. Oxford, Wiley Blackwell, pp. 571-585.

SMITH, A. (2012). Events and urban regeneration. The strategic use of events to revitalize cities. Londres, Routledge.

SMITH, N. (1996). The new urban frontier. Gentrification and the revanchist city. Londres, Routledge. (2005). "El redimensionamiento de las ciudades: la globalización y el urbanismo neoliberal". In: HARVEY, D. e SMITH, N. (eds.). Capital financiero, propiedad inmobiliaria y cultura. Barcelona, Universitat Autònoma de Barcelona, pp. 59-78. 
SMITH, N. (2009). "Ciudades después del neoliberalismo?". In: SMITH, N.; OBSERVATORIO METROPOLITANO; ROLNIK, R.; ROSS, A. e DAVIS, M. (eds.). Después del neoliberalismo: ciudades y caos sistémico. Barcelona, Universitat Autònoma de Barcelona, pp. 9-30.

TALLON, A. (2010). Urban regeneration in the UK. Londres, Routledge.

Texto recebido em 12/jun/2018

Texto aprovado em 28/ago/2018 